\title{
PENGARUH RASIONALISME ABDUH DALAM PEMIKIRAN HARUN NASUTION
}

\author{
Ahmad Nabil Amir \\ International Institute of Islamic Thought and Civilization (ISTAC- \\ IIUM) No. 24, Persiaran Tuanku Syed Sirajuddin, Taman Duta, 50480 \\ Kuala Lumpur, Malaysia \\ Email: nabiller2002@yahoo.co.uk
}

\begin{abstract}
This paper attempts to elucidate the influential impact of Muhammad Abduh's (1849-1905) rastionalism on the theological discourse of Harun Nasution (1919-1998). This was manifested in the major works of Harun such as "Kaum Mu'tarilah dan Pandangan Rasionalanya" [The Mu'tazilah and Rational Philosophy] (translated in Defenders of Reason in Islam oleh Martin et al), Mubammad Abduh dan Teologi Rasional Mu'tazilah [Jakarta: Penerbit Universitas Indonesia, 1987] (summarized from his influential doctoral thesis "The Place of Reason in Abduh's Theology: Its Impact On His Theological System And Views") that examined two monumental works of Abduh Risalab alTawhid (Theology of Unity) and Hashiyah 'ala Sharb alDawwani li al-'Aqa'id al-'Adudiyyah (Super commentary on Dawwani's Theological Work al-'Aqa'id al-'Adudiyyah) It reflected strong influence of Muhammad Abduh's philosophy on Harun, as set forth in these works. The effort to bring the modernist ideas (kaum Muda) and its theological principle was rejected by the conservative ulama. This paper try to look into Harun's liberal ideas and radical theology he
\end{abstract}


introduced based on the theological ground of $\mathrm{Mu}^{6}$ tazilism that projected rational Islam as opposed to the traditional creed of Asya'irah.

Keywords: Harun Nasution, Muhammad Abduh, Rationalism, Mu'tazilah

\section{Pengenalan}

"Orang semacam Harun Nasution, "telah memberikan 'bekas' terhadap perkembangan keIslaman di IAIN seperti menghasilkan suatu gejala umum di mana orang berani berdiskusi secara terbuka, berani mempertanyakan pandangan atau doktrin yang sudab mapan dan tidak melihat doktrin itu sebagai taken for granted."1

Kertas ini cuba melihat pengaruh yang krusial dan mendasar dari pemikiran Muhammad Abduh terhadap Harun Nasution, eksponen penting neo-mu'tazilah, dari tulisan-tulisannya yang berpengaruh. Kekentalannya memperjuangkan faham-faham moden yang ditegakkan Abduh, banyak didasari dari kekuatan pengaruh rasional yang

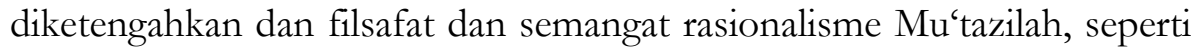
yang diungkapkan Harun "Harapanku memang cuma satu, pemikiran Asy'ariyah mesti diganti oleh pemikiran rasional $\mathrm{Mu}^{\text {'tazilah, pemikiran }}$ para filosof atau pemikiran rasional."

\section{Kehidupan}

Dilahirkan pada hari Selasa, 23 September 1919, Harun Nasution merupakan saudara keempat dari 3 beradik tuanya. Ayahnya, Abdul Jabbar Ahmad, seorang ulama, berpengetahuan luas tentang kitab-kitab jawi dan kitab-kitab kuning berbahasa melayu, kemahiran yang didapatnya dari diskusi dan penelaahannya dengan ulama-ulama setempat. Abdul Jabbar kemudiannnya diangkat menjadi kadi oleh pemerintah kolonial, sebagai kepala agama (merangkap hakim agama) dan imam masjid Kab. Simalungun. ${ }^{2}$

Abdul Jabbar, meski berpandangan tradisional, merupakan sosok ulama yang kontroversial di zamannya. Ia mengahwini putri seorang ulama asal Mandailing, yang menentang adat kerana merupakan perkawinan satu marga. Akibat tentangan, beliau pergi ke Pematang Siantar. Di kota itulah Harun Nasution dilahirkan.

1 Nurcholish Madjid, "Abduhisme Pak Harun”, dalam Aqib Suminto, ed., Refleksi Pembaharuan Islam (Jakarta: ISAF, 1989).

2 Akhiyat, "Studi Teologi Harun Nasution" (Skripsi Sarjana, Institut Agama Islam Negeri Sunan Ampel, Surabaya, 1996). 
Semua saudara Harun, kecuali yang tertua, Moh. Ayyub, mendapat pendidikan sekular. Ayyub tidak tamat sekolah dasar. Saudaranya yang lain, Khalil cuma tamat sekolah dasar, namun dia juga belajar agama dan bahasa Inggeris. Keahliannya berbahasa asing itulah kelak menyebabkannya diterima menjadi pegawai Departemen Agama di Pematang Siantar. Kakak perempuannya, Saidah, meski dipingit sejak remaja, tidak boleh sekolah, namun dapat mempelajari pengetahuan umum lewat saudaranya. Manakala Hafsah, adik Harun, kerana tidak dipingit, hidup dalam suasana lain. Beliau sempat menuntut di Taman Siswa, namun pelajarannya terganggu, kerana pendudukan Jepun di Indonesia. ${ }^{3}$

Harun lebih beruntung kerana dia dapat mengenal kebudayaan Barat. Orang tuanya memasukkannya ke sekolah Belanda. Inilah yang membukanya pada pandangan hidup yang moden dan terbuka, seperti dituturkan Harun, "lingkungan keluarganya, keterbukaan orang tua dan saudaranya, telah melapangkan jalan baginya untuk mengenal pandangan Islam modern."

Selama 7 tahun bersekolah di HIS Pematangsiantar, beliau mendalami bahasa Belanda dan ilmu pengetahuan umum. Ibunya juga berperanan dalam membentuk sikap dan disiplinnya, seperti menyuruhnya mengerjakan pekerjaan sehari-hari di rumah, seperti mencuci pinggan mangkuk dan menyapu. Pendidikan agama diperolehnya dari sang ayah yang mengajar mengaji al-Qur'an di rumah, di sebelah petang dan selepas maghrib.

Usai menamatkan pengajian di HIS, Harun melanjutkan pembelajarannya di MULO, namun orang tuanya menolak, kerana dia harus lanjut belajar agama. Akhirnya, Harun mengambil jalan tengah, ia bersedia melanjutkan pengajian ke sekolah agama asalkan belajar di perguruan Moderne Islamietische Kweekscool (MIK). Maka sejak 1934, ia mulai belajar di MIK, Bukit tinggi, di mana dia diperkenalkan dengan faham Islam moden.

Setelah itu Harun melanjutkan pengajiannya ke Mekah selama satu tahun setengah dan di fakulti usuluddin, universiti al-Azhar, Mesir pada 1938. Kemudian dia meneruskan ke Universitas Amerika di Kaherah di fakulti pendidikan, di mana dia memperoleh sarjana mudanya. Di Mesir dia mendirikan Perkumpulan Kemerdekaan Indonesia (PKI) yang aktif menyebarkan berita tentang kemerdekaan Indonesia di Mesir dan dunia Arab lainnya. Pada tahun 1953 Harun pulang ke tanah air untuk bekerja di Departemen Luar Negeri. Setelah itu dia dipindahkan ke Mekah untuk

${ }^{3}$ Ibid. 
menguruskan soal Haji selama setahun, kemudian ke Belgium, selama 3 tahun sebagai sekretaris Kedutaan.

Akhirnya beliau mengundurkan diri sebagai diplomat, dan memilih tetap tinggal di luar negara. Guru Besar mata kuliah Hukum Islam di McGill University ketika itu, Prof. HM. Rasjidi, mengundang Harun untuk menuntut di sana. Pada 20 September 1962, Harun memasuki Universitas McGill, di Kanada dengan sokongan pembimbingnya di alAzhar, Prof. Abu Zahra. Di McGill dia mengikuti kuliah dari W. Cantwel Smith, Herman Landolt, Toshihiko Izutsu, Niazi Berkes dan Ibrahim Abu Lughod. Setelah dua tahun di McGill, dia berhasil meraih ijazah sarjana (Master of Arts) dalam pengajian Islam, dengan disertasinya "The Islamic State in Indonesia: The Rise of the Ideology, the Movement for its Creation and the Theory of the Masjumi." Menurut Karel A. Steenbrink, ${ }^{4}$ nilai laporan Harun rata-rata B plus dan A. Nilai tertinggi diberikan Prof. Izutsu, iaitu 9.3 yang melayakkannya melanjut kuliah untuk meraih gelar Doktor. Beliau meraih gelar doktor pertama dari Indonesia pada Mei 1968 dalam pengaiian Islam, dengan disertasinya tentang pengaruh kalam Mu'tazilah terhadap Muhammad Abduh (The Place of Reason in 'Abduh's Theology: Its Impact on his Theological System and Views). Menurut Harun "berdasar telaah atas karya-karya M. Abduh, pemikirannya tidak identik dengan Asy'ari maupun Maturidy. Berarti dia termasuk sefaham dengan Mu'tazilah." 5

Semasa menjawat Rektor di Institut Agama Islam Negeri (IAIN) di Jakarta, dan kemudian Dekan sekolah pasca siswazah, Harun telah menggabungkan mata kuliah dalam pengetahuan tradisional Islam dengan model pengajian Barat moden, seperti sosiologi, antropologi, perbandingan agama dan falsafah sekular. Pencapaiannya ini sangat signifikan dalam memperkenalkan teologi rasional Islam, di mana "Nasutions' greatest contribution lies mainly in his attempts to introduce the rational theology of $\mathrm{Mu}^{\mathrm{c}}$ tazilism in a more comprehensive manner." ${ }^{6}$

\section{Pengaruh}

Harun Nasution merupakan intelektual Islam yang terkenal dengan pendekatan rasional dan pelopor paham-paham mu'tazilah dan prinsip serta argumen-argumen rasionalnya yang konstruktif. Meskipun ia

\footnotetext{
${ }^{4}$ Karel A. Steenbrink, "Dari Kairo Hingga Kanada dan Kampung Utan (perkembangan Pemikiran Teologis Prof. Harun Nasution)" dalam Lembaga Studi Agama dan Filsafat, Refleksi Pembaharuan Pemikiran Islam: 70 tabun Harun Nasution (Jakarta: Lembaga Studi Agama dan Filsafat, 1989), 152.

${ }^{5}$ Akhiyat, op.cit.

${ }^{6}$ Fauzan Saleh, Modern Trends in Islamic Theological Discourse in 20th Century Indonesia: A Critical Survey (Leiden: Brill, 2001), 197.
} 
disebut-sebut sebagai neo Mu'tazilah, ia sendiri menyebut dirinya sebagai seorang ahlu sunnah yang rasional. Kepentingannya dalam ranah pemikiran Islam moden di Indonesia cukup signifikan dan berpengaruh justru "Harun Nasution adalah seorang tokoh yang bisa disebut sebagai lokomotif dan gerbong pembaruan Islam di Indonesia" 7

Pengaruh Harun juga sangat kuat dalam ranah intelektual di IAIN (UIN) Syarif Hidayatullah, Jakarta dalam upaya pembaharuan yang diperkenalkannya, saat menjabat sebagai Rektornya, di mana beliau "secara berani mengajak umat Islam di Indonesia beragama secara rasional dan meninggalkan kebekuan berpikir yang telah menjadikan Islam terbelakang. Dia dengan gigih mengajak umat Islam bersikap kritis dan berijtihad secara rasional." ${ }^{8}$ Mengutip dari Guru Besar Hukum Islam Universiti Kaherah, Ali Hasballah, Harun berpendapat bahawa ijtihad itu sumber ketiga ajaran Islam setelah al-Qur'an dan Hadis. ${ }^{9}$ Dalam usahanya memperbaharui aliran teologi yang pemisif dan percubaannya membawa pemikiran liberal Barat, Harun percaya bahawa "punca keterbelakangan umat Islam adalah pada dasar teologis dan justeru dapat dirungkai dengan memperkenalkan teologi baru yang dipanggil rasionalisme Islam." 10

Pemikirannya membawa kesan yang krusial terhadap perkembangan filsafat dan teologi di Institut Agama Islam Negeri (IAIN). Hal ini diakui mantan Menteri Agama Munawir Sjadzali, yang menegaskan: "Kiranya tidak berlebihan jika saya katakan bahwa kehadiran beliau di dalam keluarga besar IAIN telah menghasilkan pola pikir yang maju dan menggalakkan keberanian berpendapat serta keterbukaan terhadap dunia luar."

Kegairahannya untuk mengubah konsep dan corak pemikiran di IAIN juga sudah dibayangkan sejak di luar negara, seperti dikisahkannya: "Aku sudah siap dengan konsep. Sejak aku masih di luar negeri, aku sudah mendengar kondisi IAIN, bahwa pemikiran di IAIN sangat sempit," 11

Corak pemikirannya yang berpengaruh terhadap praktik dasar di IAIN ini turut disingkap oleh Mohd Shuhaimi Ishak dalam penelitiannya tentang impak rasionalisme Islam Harun Nasution ke atas sistem

\footnotetext{
7 Achmad Rifki, "Mahaputra bagi Harun Nasution dan Kembalinya Islam Rasional” (15 Ogos, 2015), madinaonline.id

${ }^{8}$ Ibid.

${ }^{9}$ Ibid.

${ }^{10}$ Ishak, Mohd. Shuhaimi, Islamic Rationalism: A Critical Evaluation of Harun Nasution's Thought (Kuala Lumpur: IIUM Press, 2009).

11 Adian Husaini, Hegemoni Kristen-Barat dalam Studi Islam di Perguruan Tinggi (Jakarta: Gema Insani Press, 2006), 179.
} 
pendidikan di IAIN dan pengaruh teologi yang ia kerahkan dalam perkembangan intelek dan pemikiran agama di IAIN Indonesia. Tesisnya turut menelaah pengaruh Muhammad Abduh terhadap diskusi kalam Harun Nasution dan filsafat-filsafat rasional yang diajukannya.

Dalam pengantarnya kepada buku Pengembang Islam dan Budaya Moderat (2016) yang diterbitkan sehubungan seminar "Refleksi Pemikiran dan Kontribusi Harun Nasution di Indonesia" pada 21 Ogos 2015, Rektor UIN Syarif Hidayatullah, Prof. Dr. Dede Rosyada mencatatkan pandangannya tentang praktik dan aspirasi yang cuba dikembangkan Harun dalam struktur IAIN:

"Pak Harun merupakan salah satu tokoh penting dalam perkembangan UIN Syarif Hidayatullah, Jakarta. Betapa tidak, beliau adalah guru besar yang sekaligus menjabat Rektor untuk waktu yang sangat panjang sejak 1973 sampai 1984, dan banyak melakukan reformasi akademik, tidak hanya kurikulum dan pembelajaran, tetapi juga melakukan perubahan paradigma kajian keagamaan normatif menjadi empirik, dan kajian tariqah ablu al hadis menjadi tariqah ablu al-ra'yi bahkan tariqah al-jam'an (aliran konvergensi yang mencoba memadukan antara dua aliran ablu al hadis dan tariqah ablu al-ra'yl), dengan pendekatan komprehensif mengkaji seluruh aliran dan pemikiran, dianalisis dan disimpulkan....sosok Pak Harun sangat fenomenal, dan gerakan reformasi akademiknya sangat dirasakan oleh para mahasiswanya, sehingga kemudian, para penerus beliau menyebut kampus UIN Jakarta sebagai kampus pembaharuan, yang semua mahasiswanya harus berpandangan terbuka untuk melakukan pembaharuan, tidak saja dalam pemikiran dan sikap keberagamaan, tapi juga dalam sikap sosial dan professional mereka. Sikap reformis akhirnya menjadi identitas untuk semua alumni UIN Syarif Hidayatullah, Jakarta...Disadari atau tidak, itu merupakan salah satu jasa besar dari Pak Harun yang mengubah paradigma kajian keilmuan keagamaan di UIN Syarif Hidayatullah, Jakarta."

Kesignifikan Harun ini turut diuraikan oleh Nurcholis Madjid, dalam konteks pemikiran kalam dan peri pentingnya ide-ide progresif yang dilontarkannya dalam pembaharuan disiplin keilmuan:

"orang macam Harun telah memberikan bekas terhadap perkembangan keislaman di IAIN seperti menghasilkan suatu gejala umum dimana orang berani berdiskusi secara terbuka, berani mempertanyakan pandangan atau doktrin yang sudah mapan dan tidak melibat doktrin itu sebagai taken for granted. Dia mempertanyakan relevansi doktrin itu kepada sejarah, bagaimana kaitannya dulu dan sebagainya. Inilah yang menghasilkan 
kemampuan tertentu yang yang secara teknis disebut learning capacity, yaitu kemampuan untuk belajar" 12

Selanjutnya Madjid mengatakan,

"Yang secara substansi bisa kita lanjutkan dan kita kembangkean dari pak. Harun ialah studi atau kajian mengenai kalam (teologi) dan filsafat. Kalam oleh para abli Barat disebut teologi rasional, tidak seperti teologi kristen yang dogmatis. Kalam itu sangat dialektis dan logis"13

Menurut Madjid, "salah satu efek Harunisme adalah membuat agama menjadi fungsional, tidak hanya simbol-simbol yang sentimental dan penuh perasaan." Harun Nasution menurutnya tidak minat pada dzauqiyat tapi aqliyyah. Kerana kalau hanya dzauq, para pengikut kultus jauh lebih mantap, lebih puas dari orang yang beragama - Karena guruguru kultus selalu mengatakan: "ikut saya pasti masuk surga". Madjid juga menolak sikap beberapa sarjana yang melihat bahwa pembaharuan teologis tidak akan berdampak apa-apa pada sisi sosial ekonomi masyarakat. Ini diingkarinya. ${ }^{14}$

\section{Pembaharu Hukum}

Penganugerahan Bintang Mahaputra Utama kepada Harun Nasution oleh pemerintah sebagai Tokoh Pengembang Budaya Moderat sempena Peringatan Hari Kemerdekaan Republik Indonesia ke-70, pada 13 Ogos 2015, kiranya mengiktiraf kepeloporannya dalam pembaruan fiqh dan tauhid dimana "ia dianggap sebagai tokoh yang telah memberikan jasa luar biasa dalam pengabdian dan pengorbanan di bidang budaya dan ilmu pengetahuan.”

Kritiknya terkait figh dan tauhid, sangat membangun di mana ia mengatakan bahwa "pengajaran fikih di Indonesia menjadikan Islam terkesan sebagai agama yang hanya melulu soal halal dan haram. Mengenal Islam dari sudut pandang fikih saja memberi gambaran yang pincang tentang Islam. Apalagi jika hanya didasarkan pada satu mazhab fikih saja." 15 Tentang tauhid, ia menjelaskan bahwa "teologi Islam yang diajarkan di Indonesia pada umumnya dalam bentuk ilmu tauhid. Ilmu tauhid, selain kurang mendalam dan filosofis pembahasannya juga biasanya sepihak dan tidak mengemukakan pendapat dan paham dari aliran-aliran lain yang ada dalam teologi Islam.”16

\footnotetext{
12 Aqib Suminto, 1989, op.cit., 102-3.

13 Ibid, 104.

14 Ibid.

${ }^{15}$ Achmad Rifki, 2015, op.cit.

16 Ibid.
} 
Apresiasi pemerintah terhadap Harun juga dirakamkan dengan penganugerahan Bintang Budaya Parama Dharma pada 2014 sebagai penghargaan terhadap para pengembang dan pelestari kebudayaan. Dalam buku yang dikeluarkan oleh Direktorat Jenderal Pendidikan Islam Departemen Agama RI cetakan 2008 berjudul "Paradigma Baru Pendidikan Islam" ditegaskan penghargaan ini: "Dia mengenalkan multi pendekatan dan memperjuangkannya dengan sangat konsisten. Pengaruh pemikirannya sangat kuat di kalangan IAIN dan STAIN seluruh Indonesia dan masih dirasakan sampai sekarang."

Juga diungkapkan pengaruhnya dalam pendekatan programprogram dasar yang konstruktif "Selama menjadi rektor (1973-1984) dan setelahnya sampai tahun 1990-an sebagai Direktur pada program studi lanjutan pertama yang dibuka di IAIN Jakarta, Harun mengembangkan pemikiran Islam rasional dan menjadikan program S1 dan pasca sarjana IAIN Jakarta sebagai agen pembaharuan pemikiran dalam Islam dan tempat penyemaian gagasan-gagasan keislaman yang baru."

\section{Filsafat Rasional Mu'tazilah}

Dalam menggembleng kebangkitan mazhab rasionalisme Islam, Harun Nasution telah mempelopori perjuangan yang signifikan dalam menegakkan ideologi dan prinsip-prinsip kalam Mu'tazilah. Paham ini ditegakkan berdasar dari pemikiran dan filsafat rasionalnya. Dalam bukunya Islam Ditinjau dari berbagai aspeknya, Harun menulis: "berbeda dengan aliran-aliran teologi lainnya, aliran Asy'ariyah dan aliran Maturidiah masih ada dan inilah pada umumnya yang dianut oleh Umat Islam sekarang. Aliran Maturidiah banyak dianut oleh pengikut-pengikut mazhab Abu Hanifah. Kedua aliran inilah yang disebut Ahlussunnah. Tetapi dalam pada itu faham rasionil yang dibawa oleh kaum Mu'tazilah mulai timbul kembali di abad ke 20 ini terutama di kalangan kaum terpelajar Islam. Tetapi bagaimanapun, pengikut Asy'ariyah jauh lebih banyak daripada pengikut aliran-aliran lainnya." 17

Aspirasi Islam yang progresif yang ditinjau dari buku Islam Ditinjan dari berbagai aspeknya ini menguatkan pandangan dan prinsip muktazilah yang mendasari perbedaannya yang prinsipal dengan mazhab Asy'ariyah, di mana menurut Harun "perbedaan dasar antara Asy'ariyah dan $\mathrm{Mu}$ 'tazilah terletak pada pendapat tentang kekuatan akal. Karena $\mathrm{Mu}^{\prime}$ tazilah amat menghargai akal dan berpendapat bahwa akal manusia dapat sampai kepada ajaran dasar dalam agama yaitu adanya Tuhan dan masalah kebaikan dan kejahatan. Setelah sampai kepada adanya Tuhan dan apa yang disebut baik serta apa yang disebut jahat akal manusia dapat

${ }^{17}$ Harun Nasution, Islam di Tinjau dari Berbagai Aspeknya (Jakarta: UI Press, 1974), 41. 
pula mengetahui kewajibannya terhadap Tuhan dan kewajibannya untuk berbuat baik dan kewajiban untuk menjauhi perbuatan jahat. Wahyu dalam keempat hal ini datang untuk memperkuat pendapat akal dan untuk memberi perincian tentang apa yang telah diketahuinya itu."

"Kaum Asy'ariyah, sebaliknya, berpendapat bahwa akal tidak begitu berdaya kekuatannya. Di antara ke empat masalah di atas, akal dapat sampai hanya kepadanya adanya Tuhan. Soal kewajiban manusia terhadap Tuhan, soal baik dan buruk (jahat) dan kewajiban berbuat baik serta kewajiban menjauhi kejahatan itu tidak dapat diketahui akal manusia. Itu diketahui manusia hanya melalui wahyu yang dikirimkan Tuhan melalui para Nabi dan Rasul."

"Kalau kaum Mu'tazilah banyak percaya pada kekuatan akal manusia kaum Asy'ariyah banyak bergantung kepada wahyu. Sikap yang dipakai kaum Mu'tazilah ialah mempergunakan akal dan kemudian memberi interpretasi pada teks atau nas wahyu sesuai dengan pendapat akal. Kaum Asy'ariyah sebaliknya pergi terlebih dahulu kepada teks wahyu dan kemudian membawa argumen-argumen rasionil untuk teks wahyu itu. Kalau kaum Mu'tazilah banyak memakai ta'wil atau interpretasi dalam memahami teks wahyu, kaum Asy'ariyah banyak berpegang pada arti lafzi atau letterlek dari teks wahyu. Dengan lain kata kalau kaum Mu'tazilah membaca yang tersirat dalam teks, kaum Asy'ariyah membaca yang tersurat."

"Selain dari itu, faham al-Kasb yang dibawa kaum Asy'ariyah lebih dekat kepada faham Jabariah atau fatalisme kepada faham qadariah atau kebebasan manusia. Dan karena kuat mempertahankan faham kekuasaan mutlak Tuhan, faham hukum alam atau sunnatullah akhirnya tidak mendapat tempat dalam aliran Asy'ariyah". ${ }^{18}$

Pemahaman epistemologinya seputar prinsip teologis $\mathrm{Mu}^{\text {'tazilah }}$ yang ditinjau dari bukunya Islam Ditinjau dari berbagai aspeknya ini, menzahirkan pandangan rasional yang signifikan yang dirumuskan dari idealisme dan pandangan sarwa Abduh yang progresif, di mana "ia menggugat cara beragama di Indonesia yang tampak sempit." 19

Dalam ikhtiarnya mengembangkan gagasan rasional yang dilontarkan Abduh seputar prinsip dan faham pembaharuan Islam, Harun telah merumuskan sistem dan falsafah penting dari fikiranfikirannya yang konklusif, tentang paham-paham rasional Mu'tazilah, yang cuba digarap dan dikembangkan di mana "akan halnya Prof. Harun Nasution, gagasannya tentang perlunya dikembangkan teologi rasional Mu'tazilah dan pendapatnya yang menolak adanya Negara Islam,

\footnotetext{
${ }^{18}$ Ibid, 42.

${ }^{19}$ Achmad Rifki, op.cit.
} 
misalnya, telah memberikan landasan normatif khususnya bagi kalangan cendikiawan dan profesional muslim untuk berpartisipasi aktif dalam pembangunan ini, tanpa ada kekhawatiran dituding mengkhianati agamanya." 20

Paham dan hujah yang ditegakkannya sempat mengilhamkan pembenturan dan kebangkitan ideologi rasional berdepan dengan mazhab tradisional dan tak terlepas dari menimbulkan keresahan dan kegelisahan umum, di mana "Tidak dipungkiri, sepak-terjang Harun memang sempat menimbulkan pergolakan di kalangan kaum Muslimin. Namun, sekali lagi, itu semata-mata dilakukannya demi kemajuan Islam. Dan Islam, menurutnya, harus mampu menyesuaikan diri dengan perkembangan serta kemajuan zaman." 21

\section{Sang filosofis}

"Pembicaraanku seringkali terlalu filosofis. Maka setiap kali aku diminta untuk berbicara di masjid, kubilang tidak bisa. Aku tidak bisa bercerita dongeng kepada mereka. Sebab, dongeng tidak masuk akal bagiku." Harun Nasution

Dalam karyanya Falsafat Islam, Harun Nasution menguraikan tentang dasar-dasar agama yang ditinjau secara filsafat, seperti keberadaan Tuhan; yang menawarkan penjelasan yang lebih dapat diterima akal kepada penghujat wahyu yang hanya berpegang pada rasio dan daya taakul. Argumen-argumen rasional yang dielaskan secara filsafat di setiap babnya memungkinkan hujahnya ditanggapi oleh semua bahkan kalangan ateis. Menurutnya, "pengetahuan agama tidak selalu menggunakan wahyu, melainkan juga dengan penggunaan bukti-bukti historis, argumen-argumen rasional tentang agama dapat mempertebal keimanan seseorang." Dan dalam buku ini "ia berusaha untuk mengisbatkan ajaran Islam sangat rasional dan dapat dibuktikan." Dalam rangka pembaharuan dan penegasan sifat rasional dan ijtihad buku ini menghimbau bahwa pendidikan tradisional harus dirubah dengan memasukkan mata pelajaran dari ilmu pengetahuan moden dalam kuliah di madrasah, dan sistem pemerintahan yang mutlak harus digantikan dengan kerajaan demokratik berasaskan prinsip konstitusional.

Dalam bukunya Islam Rasional: Gagasan dan Pemikiran Harun Nasution cuba mengangkat aspirasi rasional yang didengungkan dalam al-Qur'an dan Sunnah, di mana menurutnya, "Islam sangat rasional

\footnotetext{
${ }^{20}$ Choirul Anam, "Dari Teologi Rasional hingga Konsep Negara Islam Menelusuri Jejak Pemikiran Harun Nasution" (Skripsi Sarjana, IAIN Sunan Ampel, Surabaya, 1992).

${ }^{21}$ Iswara N Raditya, "Memadukan Wahyu dan Akal: Berislam ala Harun Nasution" (15 Mei 2018), tirto.id - Humaniora.
} 
apalagi dalam beragama tidak ada yang tidak bisa diterangkan oleh akal." Peranan akal yang krusial ini dipertahankan dengan prinsip dan paham mazhab mu'tazilah dan filsafat rasionalnya, di mana menurutnya "teologi rasional diwarnai dengan kedudukan akal yang tinggi, kebebasan manusia dalam kehendak serta perbuatan, keyakinan akan adanya hukum alam ciptaan Tuhan dan kecendrungan untuk mengambil arti tersirat dari teksteks wahyu yang arti lafaznya tak sejalan dengan pemikiran rasional dan ilmiah" 22

Ideal dan pandangan dinamik ini digarap daripada pemikiran Abduh yang mengajarkan kemerdekaan dan kebebasan akal, seperti dicatatkan Robert R. Relly dalam bukunya The Closing of the Muslim Mind: How Intellectual Suicide Created the Modern Islamist (bab 7: The Wreckage: Muslim Testimonials): (conservative ulama) asking if he had given up Asha'rite teaching to follow the Mu'tazilite," jawab Abduh, "If I give up blind acceptance (taqlid) of Asha'rite doctrine, why should I take up blind acceptance of the Mu'tazilite?"

[ulama konservatif bertanya jika dia telah meninggalkan ajaran Ash'ari untuk mengikut mazhab Mu'tazilah? Jawab Abduh "Jika aku telah meninggalkan bertaklid kepada doktrin Ash'ariyah, mengapa aku harus pergi bertaklid kepada Mu'tazilah?] ${ }^{23}$

Pada asasnya buku ini cuba menangkis kejumudan, dan sikap taklid yang melulu di tengah umat di mana menurutnya "banyak kaum muslim hanya mengikuti dogma yang merupakan hasil ijtihad para ulama di zaman klasik, padahal dengan menolak sikap taklid mereka seharusnya tidak terikat kepada ajaran yang dihasilkan ijtihad ulama masa silam" 24 Dalam buku Islam Rasional (yang merupakan himpunan makalahnya antara 1970-1994) ini Harun mengerahkan pemikiran rasional yang meyakinkan dan melontarkan beberapa kemungkinan bagi menjawab ketertinggalan dan keterbelakangan kita. Yakni dengan menyingkap lembaran sejarah tentang period klasik Islam, di mana para ulama sanggup membezakan antara ajaran dasar Islam yang bersifat absolut (dalam al-Qur'an dan Hadith) dengan yang bukan dasar dan sifatnya tidak mutlak. Ini jauh berbeza dengan period pertengahan (bermula dengan kejatuhan Baghdad hasil penyerbuan Hulagu Khan pada 1258) di mana ulama-ulama zaman pertengahan menganggap ajaran-ajaran ulama klasik turut diyakini sebagai dogma, sehingga ajaran-ajaran relatif ini

\footnotetext{
${ }^{22}$ Harun Nasution, Islam rasional gagasan dan pemikiran (Jakarta: Lembaga Studi Agama dan Filsafat, 1989), 341.

${ }^{23}$ Robert R. Relly, Tertutupnya Pemikiran Kaum Muslimin, terj. Shuhaib Ar Rumy Ismail, ed. Ahmad Farouk Musa (Kuala Lumpur: Islamic Renaissance Front, 2017).

${ }^{24}$ Harun Nasution (1989), op.cit., 154.
} 
mengikat kebebasan berfikir dan bergerak. Makanya, kata Harun “jika ajaran yang nisbi itu tidak sesuai dengan perkembangan zaman sekarang, bisa saja ditinggalkan untuk kemudian mencari penyesuaiannya dengan tetap mengacu kepada Al-Quran dan Hadits." ${ }^{25}$

Harun juga menekankan tentang faham teologi yang dianut ulama period klasik yaitu teologi rasional, atau qadariyah (kehendak bebas, kemerdekaan manusia), yang mendorong pencapaian kreatif dan dinamik dan sikap keterbukaan bertentang dengan umat zaman pertengahan yang menganut paham jabariyah (fatalisme, keterpaksaan manusia) yang beranggapan nasib sudah ditentukan Tuhan sejak azali. Inilah yang cuba dipecahkan Harun dalam merekonstruksi dan memulihkan kekuatan umat muslim.

Dalam upaya mendakyahkan ideologi kaum $\mathrm{Mu}^{\text {'tazilah dan }}$ merangsang umat untuk berfikir, ia cuba mengajukan upaya ini secara filosofis, kerana "bagi Harun Nasution, kebangkitan Islam tidak harus dilakukan dengan emosi yang meluap-luap, melainkan dengan pemikiran yang dalam, menyeluruh, dan filosofis." 26

Bukunya "Islam ditinjau dari berbagai aspeknya" meninjau aspek-aspek pokok dari segi-segi pemikiran dan falsafah pengetahuan Islam yang dinamik. Tulisannya ini telah mendapat sanggahan dan tantangan hebat dari sebahagian ulama dan cendekiawan dan beberapa pihak yang menzahirkan "pernyataan-pernyataan tidak setuju dengan cara penulisan buku tersebut". Tangkisan yang menarik oleh Prof. Dr. H.M. Rasjidi dalam bukunya "Koreksi terhadap Dr. Harun Nasution tentang "Islam ditinjau dari berbagai aspeknya" dan "Koreksi Prof. Dr. H.M. Rasjidi terbadap Prof. Dr. Harun Nasution dalam Uraiannya "Ajaran Islam tentang Akal dan Akblak" menampakkan kegelisahan dan keberatan terhadap pandangan yang ditampilkan yang sedemikian rupa disanggahnya dalam mendudukkan persoalan tersebut secara ilmiah, meskipun Prof. Dr. H.M. Rasjidi merasakan kedangkalan dalam kesimpulan-kesimpulan yang dibuat oleh Harun Nasution tentang aspek-aspek ketuhanan, pembaharuan Islam, dan tasawuf, dimana "kalau soalnya begitu, maka saya dengan sangat menyesal terpaksa mengatakan bahwa penulis buku tersebut belum memahami ajaran-ajaran Islam." ${ }^{27}$

\footnotetext{
25 M Mushthafa, "Rasionalisme Menuju Dinamisme" (Resensi Buku "Islam Rasional, Gagasan dan Pemikiran") Majalab Mimbar Pembangunan Agama (MPA) (Departemen Agama Jawa Timur, April, 1996).

${ }^{26}$ Iswara N Raditya, 2018, op.cit.

${ }^{27}$ H.M. Rasjidi, Koreksi terbadap Dr. Harun Nasution: tentang "Islam ditinjau dari berbagai aspeknya" (Jakarta: Bulan Bintang, 1977),145.
} 
Buku ini ditulis sebagai teks dasar dalam kuliah pengantar Ilmu Agama Islam dan pada awalnya diterima dengan positif oleh khalayak sebagai ringkasan aspek-aspek Islam yang dinamik, seperti dicatatkan Dr. Mulyanto Sumardi, Kepala Direktorat Perguruan Tinggi, Departemen Agama dalam kata sambutannya: "buku Islam Ditinjau dari berbagai aspeknya (adalah) suatu buku yang akan bermanfa'at terutama untuk mata kuliah Pengantar Ilmu Agama Islam - mata Kuliah Komponen Institut yang wajib diambil oleh setiap mahasiswa I.A.I.N. apapun fakultas dan jurusannya, seperti yang telah ditetapkan dalam rapat Kerja Rektor I.A.I.N. se Indonesia di Ciumbuluit Bandung, bulan Agustus 1973." 28

Tetapi selang beberapa waktu kemudian tercetus ketegangan dan keresahan di kalangan umum dan cendikiawan yang melahirkan ketidak setujuan terhadap buku tersebut, mengingat beberapa kekeliruan dalam pandangan dan keterangan-keterangannya dalam "menguraikan filsafat Ibnu Rusyd yang tidak senafas dengan Islam" dan "kesalahan faham yang bukan-bukan" hasil meresapnya faham neo Platonisme, "kurang memenuhi integritas ilmiyah" bahkan "mengandung gejala-gejala pengaruh negatif dari orientalisme atau pengajian Islam dengan cara Barat" serta penyimpangannya dalam menafsirkan soal-soal agama, sejarah, politik, hukum, filsafat, teologi, dan mistisisme yang "hanya menimbulkan kekacauan dalam fikiran generasi muda" ${ }^{29}$

\section{Dasar Teologis}

Teologi rasional yang dirumuskan dari pandangan moden Abduh mengilhamkan penetrasi-penetrasi dan pendalaman-pendalaman filsafat, serta sistem pemikiran yang progresif yang cuba diketengahkan Harun dalam pemikiran moden yang berkembang di Indonesia, dengan menafikan aliran Asy'ariyah dengan pandangan $\mathrm{Mu}^{\prime}$ tazilah, yang lebih dipahami kaum terpelajar, di mana "Hal-hal inilah antara lain yang membuat aliran Asy'ariyah kurang sesuai dengan jiwa kaum terpelajar yang banyak mendapat pendidikan Barat. Dalam suasana serupa inilah orang mulai kembali ke faham-faham rasionil yang dibawa kaum Mu'tazilah. Teologi atau falsafat hidup Asy'ariyah yang mempunyai corak traditional itu kurang sesuai dengan pandangan hidup mereka, yang lebih dapat mereka terima ialah teologi atau falsafat hidup $\mathrm{Mu}^{\text {'tazilah yang }}$ lebih banyak mempunyai corak liberal." ${ }^{30}$

Perkembangan mazhab dan pengaruh dari karya-karya Abduh telah memberi dampak luar biasa di dunia Islam dan terutamanya kepulauan

\footnotetext{
${ }^{28}$ Ibid, 5.

${ }^{29}$ Ibid, 129.

${ }^{30}$ Harun Nasution, Islam ditinjau dari Berbagai Aspeknya (Jakarta: UI Press, 1985), 43.
} 
Melayu-Indonesia, di mana, menurut Harun "Pemikiran-pemikiran Mu'tazilah mulai ditimbulkan kembali oleh pemikiran-pemikiran pembaharuan dalam Islam abad 19 seperti Jamaludin al Afgani, Muhammad Abduh dan Ahmad Khan di India." 31

Harun menyimpulkan (sebagai dirumuskan dalam tesisnya), bahwa pengaruh Muhammad Abduh telah menyebar luas di nusantara kerana impak yang signifikan dari idea-ideanya yang revolusioner dan gagasan modennya yang telah membangkitkan kesedaran baru dalam pemikiran kaum Muslim di Indonesia "It is under the impact of his ideas, which came into the country through al-Urwah al-Wuthqa, al-Manar dan through his own works such as Tafsir al-Manar and Risalah al-Tawbid, that modernism in Indonesian Islam was inaugurated in the first decade of this century." 32

[Di bawah kesan dari idea beliaulah, yang menyerbu ke negara ini melalui al-Urwah al-Wuthqa, al-Manar dan melalui karya-karya beliau sendiri seperti Tafsir al-Manar dan Risalah al-Tawhid, di mana gelombang modernisme di Indonesia Islam dibuka dalam dekad pertama dari abad ini].

Dalam bukunya Islam ditinjau dari Berbagai Aspeknya Harun menulis: "Pendapat yang banyak dianut dalam kalangan Ahlussunnah bahwa pintu ijtihad tertutup mulai mendapat tantangan oleh pemikir-pemikir pembaharuan dalam Islam di akhir abad 19 yang lalu seperti al-Tahtawi, Jamaluddin al Afgani dan Muhammad Abduh." 33

Akan halnya kaidah akliah yang dikembangkan Abduh yang menegakkan hujah dan dasar rasional Mu'tazilah, yang dipertahankan Harun, sebagai prinsip yang diperkukuh dan didasarkan dari ideologi hukum Islam. Menanggapi hal ini Harun menyatakan:

"Yang membuat umat Islam banyak bersifat statis ialah karena merasa terikat pada ajaran-ajaran bukan dasar yang dihasilkan zamanzaman yang silam, yaitu ajaran-ajaran bukan dasar yang tidak sesuai lagi dengan kondisi zaman modern. Hakekat inilah yang disadari kaum pembaharu Islam, dan untuk pembaharuan, mereka melihat bahwa penafsiran atau ajaran-ajaran bukan dasar yang tidak sesuai dengan zaman harus ditinggalkan. Sebagai penggantinya perlu diadakan ajaran bukan dasar baru dengan menimbulkan penafsiran baru dari ajaran dasar yang terdapat dalam Al Qur-an dan Hadis. Yang mereka maksud dengan

\footnotetext{
${ }^{31}$ Ibid.

32 Harun Nasution, "The Place of Reason in Abduh's Theology: Its Impact on his Theological System And Views" (Tesis Ph.D., Institute of Islamic Studies, McGill University, Montreal, 1968, 1.

${ }^{33}$ Harun Nasution (1985), op.cit., 21.
} 
meninggalkan taqlid ialah meninggalkan ajaran-ajaran bukan dasar itu, dan dengan kembali kepada ajaran dasar dan menyesuaikan penafsirannya dengan tuntutan zaman."

"...Oleh karena itu tidaklah berdasar anggapan bahwa umat Islam mundur, karena agama Islam merupakan penghambat bagi kemajuan. Umat Islam lambat dalam geraknya mencapai perobahan dan kemajuan, bukan karena agama Islam, tetapi karena umat Islam masih terikat pada tradisi nenek moyang. Dalam tiap masyarakat, tradisi memang merupakan penghambat besar bagi tiap usaha-usaha modernisasi, apalagi kalau tradisi itu dianggap mempunyai sifat sakral." 34

Pandangan hidup yang ideal dan instruktif ini menekankan pentingnya kesedaran dan kekuatan daya akliah dan ijtihad dan keperluannya yang mendasar dalam mengilhamkan kebangkitan dan menggerakkan perjuangan yang bermakna dalam upaya pembaharuan.

\section{Pengaruh Abduh}

Terinspirasi dari keaslian pemahaman Abduh dan rumusanrumusan akliah yang fundamental dan ideologi pemikiran yang penting yang dilakarkannya tentang faham-faham Mu'tazilah dan khittah dasarnya yang progresif, Harun cuba menyerbukan pandangannya dalam upaya menggempur benteng Asya'irah dan mendobrak faham jabariyah dan fatalisme dan sikap penyerahan yang pasrah kepada takdir, dan menolak faham jumud dan kolot di mana "pemikiran Abduh ini sangat mengena dalam pemahaman Harun. Menurutnya, yang juga menjadi penyebab kemunduran umat Islam di Indonesia tidak lain adalah kejumudan." 35

Faham rasional Abduh, dan kerangka pemikiran yang dibawanya, dakwa Harun, mempunyai persamaan dengan paham rasional kaum Mu'tazilah, di mana kesimpulan penelitian doktoralnya menyatakan "Muhammad Abduh...mempunyai pendapat-pendapat Mu'tazilah" dan pada pengantar bukunya Mubammad Abduh dan Teologi Rasional Mu'tarilah bahawa "pemikiran teologi Muhammad Abduh banyak persamaannya dengan pemikiran teologi kaum Mu'tazilah". Kekuatan prinsip dan kaidah rasional yang diajukan Abduh inilah yang cuba ditegakkan dari kerangka akliah dan pandangan dunia Islam yang moden, sebagai dirumuskan oleh Nurcholish Madjid: "Kita mengetahui tokoh yang nampaknya paling banyak diketahui Pak Harun adalah Syekh Muhammad Abduh...dan itu dibuktikannya melalui berbagai penelitiannya. Sebagai seorang pengagum Muhammad Abduh, pak

\footnotetext{
34 Ibid, 113.

35 Iswara N Raditya, 2018, op.cit.
} 
Harun boleh disebut "Abduhis" sekali. Etosnya terhadap rasionalitas dan ilmu pengetahuan sangat kuat. Karena etos ilmiahnya kuat sekali, maka dalam hal ini disebut modern. Karena itu Muhammad Abduh memperoleh nama sebagai seorang modernis." 36

Kekuatan dan asas-asas pemikiran kalam yang disuguhkannya mengilhamkan pembaharuan dan kebangkitan teologi moden mu'tazilah, yang menginspirasikan Harun, dimana "aspek pembaharuan itulah yang merupakan benang merah dari pemikiran Harun yang meliputi, pembaharuan teologi, filsafat, dan pemikiran politik Islam, sehingga pendekatan keilmuan Harun lebih liberal bila dibandingkan tokoh pembaharu sezamannya" 37

Perjuangannya menegakkan pandangan agama yang rasional dalam dunia moden dan melanjutkan projek pembaruan Islam ini sangat krusial dan bermakna, di mana "di tengah maraknya isu-isu disharmonis, ketidakrukunan, kekerasan bahkan konflik, yang mengatasnamakan agama, maka pemikiran Islam rasional yang digagas oleh Harun Nasution merupakan solusi tawaran dalam memahami agama dalam rangka menwujudkan kerukunan umat beragama." 38

\section{Al-Urwatul Wutsqa}

Mengambil dari filsafat dan pandangan rasional Abduh yang dinamik, dan pemahaman Islamnya yang moden dan konkrit, Harun cuba mengembangkan asas-asas rasional dan prinsip ijtihad yang diilhamkannya, dan menegakkan ajaran-ajaran filsafat yang konstruktif yang dikembangkannya dalam al-Urwah al-Wuthqa fi al-Sabwah al-Kubra yang telah menghasilkan kekuatan yang dahsyat dalam mengancam aspirasi kolonial dan kuasa imperialisme Barat. Menurut keterangan H.M. Rasjidi, "Al-Urwatul Wutsqa yang hanya terbit 18 kali, pada tahun 1884 telah berjasa membuka mata umat Islam tentang penjajahan barat khususnya Inggris di India dan Mesir" ${ }^{39}$

Di mana menurut Harun, diterangkan di dalam al-Urwah al-Wuthqa bahawa faham Qada' dan Qadar telah diselewengkan menjadi fatalisme (jabriyyah) menyebabkan umat mundur. Padahal, sebenarnya faham itu mengandung arti dan esensi yang dinamis, yang mendorong umat maju. Walhasil, faham jabariyah (keterpaksaan manusia) yang mengakar dalam pemahaman kaum Muslimin sekarang perlu dirubah kepada paham kebebasan dalam kehendak dan perbuatan seseorang layaknya paham

\footnotetext{
${ }^{36}$ Nurcholish Madjid, 1989, op.cit., 103, A. Akhiyat, 1996, op.cit.

37 Akhiyat, Ibid.

38 Muhammad Irfan, , "Paradigma Islam Rasional Harun Nasution: Membumikan Teologi Kerukunan” JIS A: Jurnal Ilmiah Sosiologi Agama, 1 (1), 2018), 109-127.

${ }^{39}$ H.M. Rasjidi (1977), op.cit., 136.
} 
mu'tazilah, yang akan menimbulkan kedinamisan dan kebangkitan umat semula.

Sejarah tentang pemikiran dan aliran teologi Mu'tazilah dan posisinya sebagai kaum rasionalis dicatatkan oleh Shahrastani dalam karya klasiknya al-milal wa al-nihal, "The Mu'tazilah are incontestably rationalists, in the true sense of the term, in that they consider that certain awareness are accessible to man by means of intelligence alone, in the absence of, or prior to, any revelation" 40

Harun membezakan aspirasi pembaharuan Islam yang rasional, yang digerakkan Abduh yang menekankan semangat rasional dan kebebasan, dengan diktat Ash'ariyyah, di mana "because of his position of ascribing great powers to reason and limited functions to revelation, his system and views are in glaring contradiction with those of the Ash'ariyah who have a distrust in the power of reason and great reliance on revelation. His system and views, on the other hand, greatly resemble those of the Mu'tazilah who have been well-known for their high appreciation of the power of reason and little reliance on revelation" 41

[disebabkan pendirian beliau yang menisbahkan kekuatan yang besar kepada akal dan fungsi yang terbatas kepada wahyu, sistem dan pandangan beliau berseberangan secara menyolok dengan kaum Ash'ariyah yang mencurigai keupayaan akal dan meletakkan pergantungan yang besar ke atas wahyu. Sistem dan pandangan beliau, sebaliknya, sangat menyerupai kaum Mu'tazilah yang terkenal dengan penghargaan mereka yang tinggi terhadap kesanggupan akal dan sedikit pergantungan kepada wahyu].

Dalam bukunya yang menjadi rujukan dasar dalam perguruan tinggi Islam, Teologi Islam: Aliran-aliran, Sejarah, Analisa, Perbandingan (1986), Harun menegaskan bahwa "perpaduan pemikiran Abduh dan konsep mu'tazilah mampu membawa masyarakat menjauh dari kekacauan, bahkan tanpa turunnya wahyu sekalipun" ${ }^{42}$

Berkat pemikiran dan gagasan yang ditegakkan berdasar dari prinsip rasional dan filsafatnya yang mendasar.

\section{Kesimpulan}

Terkesan dengan upaya pembaharuan yang digerakkan Abduh, Harun Nasution cuba mengembangkan pengaruh dan idealisme rasional

\footnotetext{
40 'Abd al-Karim al-Shahrastani, Kitab al-milal wa al-nihal (Kaherah: Mu'assasah al-Halabi, 1967), terj. A.K. Kazi dan J.G. Flynn (London: Kegan Paul International, 1984), 45.

${ }^{41}$ Harun Nasution, 1968, op.cit.

42 Harun Nasution, Teologi Islam: Aliran-aliran, Sejarah, Analisa, Perbandingan (Jakarta: Yayasan Penerbit Universitas Indonesia, 1978), 47.
} 
yang diilhamkannya, bagi menggembleng harakat dan idealisme perjuangan dan membawa semangat kebebasan dan ijtihad.

Aspirasi moden ini digerakkan berdasar dari pemikiran dan teologi rasional yang diperjuangkan. Mengambil dari filsafat dan pandangan rasional Abduh yang radikal, beliau cuba mengangkat ajaran-ajaran filsafat dan asas-asas rasional yang diilhamkannya, bagi menentang kejumudan dan mendobrak benteng taklid, dan mengembangkan filsafat dan pandangannya yang signifikan yang mempertahankan posisi nalar yang esensil "yang mengedepankan akal dalam menyelesaikan problem teologis" 43

Idealisme perjuangan yang berpengaruh dan filsafat rasional yang ditegakkan memberi kesan yang mendalam terhadapnya, di mana "Jamaludin Al Afghani atau Muhammad Abduh...mereka adalah orangorang yang ingin membangkitkan Umat Islam dari keterlambatannya dan kebodohannya, agar mereka dapat mempertahankan diri dari imperialisme Barat yang pada waktu itu merajalela dimana-mana." ${ }^{4}$

Dasar pemikiran yang mendorong daya akliah dan ijtihad ini sangat mengesankannya, di mana "Harun sangat tidak tertarik dengan ulamaulama yang menimbulkan paham taklid buta di kalangan umat dan menyebabkan orang Islam berhenti menggunakan akalnya. Sikap seperti itu bahkan dipandang Harun bertentangan dengan Alquran dan Hadis." 45

\section{Rujukan}

'Abd al-Karim al-Shahrastani, Kitab al-milal wa al-nibal (Kaherah: Mu'assasah al-Halabi, 1967), terj. A.K. Kazi dan J.G. Flynn (London: Kegan Paul International, 1984).

'Abu' al-Hasan 'Alī ibn Ismā'îl al-Ash'arî̀s al-Ibānah 'an usūl ad-diyānah (The Elucidation of Islam's Foundation). Terj. Walter C. Klein (American Oriental Series. Vol. 19.) New Haven: American Oriental Society, xiii + 143, 1940.

Achmad Rifki, "Mahaputra bagi Harun Nasution dan Kembalinya Islam Rasional" (15 Ogos, 2015), madinaonline.id

Adenan, Ilhamuddin, Amroeni Drajat, "The Contribution of Harun Nasution's Thoughts in Islamic Reform in Indonesia" IOSR Journal of Humanities and Social Science (IOSR-JHSS) 22 (8) II. 66-74, 2017.

\footnotetext{
43 Achmad Rifki, 2015, op.cit.

${ }^{44}$ H.M. Rasyidi, 1977, op.cit., 110.

${ }^{45}$ Harun, 1996, op.cit, 175, Iswara N Raditya, 2018, op.cit. 
Adian Husaini, Hegemoni Kristen-Barat dalam Studi Islam di Perguruan Tinggi (Jakarta: Gema Insani Press, 2006).

Akhiyat, "Studi Teologi Harun Nasution" (Skripsi Sarjana, Institut Agama Islam Negeri Sunan Ampel, Surabaya, 1996).

Choirul Anam, "Dari Teologi Rasional hingga Konsep Negara Islam Menelusuri Jejak Pemikiran Harun Nasution" (Skripsi Sarjana, IAIN Sunan Ampel, Surabaya, 1992)

Fauzan Saleh, Modern Trends in Islamic Theological Discourse in 20th Century Indonesia: A Critical Survey (Leiden: Brill, 2001).

Harun Nasution, "The Islamic State in Indonesia: The Rise of the Ideology, the Movement of its Creation, and the Theory of the Masjumi" (Tesis M.A., Institute of Islamic Studies, McGill University, Montreal, 1965).

, "The Place of Reason in Abduh's Theology: Its Impact on his Theological System And Views" (Tesis Ph.D., Institute of Islamic Studies, McGill University, Montreal, 1968).

1973).

Filsafat dan Mistisisme dalam Islam (Jakarta: Bulan Bintang, , Islam di Tinjau dari Berbagai Aspeknya (Jakarta: UI Press, 1974). - Pembaharuan dalam Islam Sejarah Pemikiran dan Gerakan (Jakarta: Bulan Bintang, 1975).

Teologi Islam: Aliran-aliran, Sejarah, Analisa, Perbandingan (Jakarta: Yayasan Penerbit Universitas Indonesia, 1978). , Islam ditinjau dari Berbagai Aspeknya (Jakarta: UI Press, 1985). , Akal dan Wabyu dalam Islam (Jakarta: Penerbit Universitas Indonesia, 1986). , Islam rasional gagasan dan pemikiran (Jakarta: Lembaga Studi Agama dan Filsafat, 1989).

, Pembaharuan dalam Islam: Sejarah Pemikiran dan Gerakan (Jakarta: PT Bulan Bintang, 1991). , Falsafat Agama (Jakarta: Bulan Bintang, 2003).

H.M. Rasjidi, Koreksi terbadap Dr. Harun Nasution: tentang "Islam ditinjau dari berbagai aspeknya" (Jakarta: Bulan Bintang, 1977).

H. Aqib Suminto et. all., Refleksi Pembaharuan Pemikiran Islam: 70 tahun Harun Nasution (Ciputat: Lembaga Studi Agama dan Filsafat, 1989).

Ishak, Mohd. Shuhaimi, Islamic Rationalism: A Critical Evaluation of Harun Nasution's Thought (Kuala Lumpur: IIUM Press, 2009).

, "The Role of Intellect $(A l-A q D)$ in the Discourse of Harun Nasution" Jurnal Usuluddin, (30) 111-133, 2009. 
"The Influence of Muhammad 'Abduh on Harun Nasution's Theological Discourse”. Hamdard Islamicus, XXXIII (1), 31-50, 2010.

Iswara N Raditya, "Memadukan Wahyu dan Akal: Berislam ala Harun Nasution" (15 Mei 2018), tirto.id - Humaniora.

Karel A. Steenbrink, "Dari Kairo Hingga Kanada dan Kampung Utan (perkembangan Pemikiran Teologis Prof. Harun Nasution)" dalam Lembaga Studi Agama dan Filsafat, Refleksi Pembaharuan Pemikiran Islam: 70 tabun Harun Nasution (Jakarta: Lembaga Studi Agama dan Filsafat, 1989).

M Mushthafa, "Rasionalisme Menuju Dinamisme" (Resensi Buku "Islam Rasional, Gagasan dan Pemikiran") Majalab Mimbar Pembangunan Agama (MPA) (Departemen Agama Jawa Timur, April, 1996).

Muhammad Irfan, "Paradigma Islam Rasional Harun Nasution: Membumikan Teologi Kerukunan" JISA: Jurnal Ilmiah Sosiologi Agama, 1 (1) 109-127, 2018.

Nurcholish Madjid, “Abduhisme Pak Harun”, dalam Aqib Suminto, ed., Refleksi Pembaharuan Islam (Jakarta: ISAF, 1989).

Richard C. Martin, Mark R. Woodward, Dwi S. Atmaja, Defenders of Reason in Islam: Mu'tazilism from Medieval School to Modern Symbol (Oxford: Oneworld Publications, 2003).

Sohirin Mohammad Solihin, Emergence and Development of Liberal Islam in Indonesia: A Critical Evaluation (Kuala Lumpur: IIUM Press, 2009). 